\title{
Cytotoxic Evaluation of Annatto (Bixa orellana L.) Dye Compared with Orange Red
}

\author{
Nisha Joseph and E. A. Siril* \\ Department of Botany, University of Kerala Kariavattom, Thiruvananthapuram 695 581, India
}

Received February 17, 2010; accepted June 21, 2010

\begin{abstract}
Summary Cytotoxic evaluation of annatto (Bixa orellana L.) seed pulp extract on Allium cepa root tip cells was carried out. The annatto dye was extracted using different solvents viz. alkaline water, ethyl alcohol and chloroform: alcohol mixture $(1: 3)$. Crude extract evaporated and dry residual powder recovered. The powder was dissolved in water at different concentrations $(0.1 \%, 0.5 \%$ and $1 \%)$ and was used to treat onion root tips for $12 \mathrm{~h}$ and the mitotic behaviour was recorded. The results were compared with a synthetic dye orange red at 2 concentrations $(0.05$ and $0.1 \%)$. Annatto extracts treated cells showed normal mitotic behaviour whereas orange red $(0.1 \% \mathrm{w} / \mathrm{v})$ showed complete arrest of cell division. The synthetic dye at low concentration $(0.05 \% \mathrm{w} / \mathrm{v})$ showed diverse forms of mitotic abnormalities like single or double nuclear lesions, single, double or multiple bridges, metaphase clumping, tropokinensis and chromosome fragments. Cyototoxicity test system based on $A$. cepa root tips has proved that annatto dye is significantly less toxic compared to its synthetic alternative, orange red.
\end{abstract}

Key words Allium cepa, Annatto dye, Bixa orellana, Cytotoxicity, Mitotic abnormalities, Orange red.

Food additives are a large group of substances that are added to foods directly or indirectly either during the storage or processing of foods (Leung and Foster 1996). Among the diverse groups of food additives, colouring agents occupy a prime position, as they have direct influence on consumer acceptance. Annatto placed as the second most important natural food colourant and is one of the 13 natural food colours listed by the US-FDA. It is an orange red seed specific carotenoid pigment synthesized by a single terrestrial plant Bixa orellana (Family Bixaceae). Annatto dye is mainly composed of 2 carotenoid pigments, bixin and norbixin (Kapoor 2006). Annatto can be used as a substitute to synthetic dyes in food and cosmetic industries. Annatto dyes are natural; however, cytotoxicological and cyto-hazardous evaluations are a pre-requisite prior to promote the species. In this direction not much attention has been given so far, with a few exceptions (Hagiwara et al. 2003, Paumgartten et al. 2002, Aranez and Rubio 1996). The present investigation aims to analyze the effect of annatto using A. cepa root tip cells as a test system.

\section{Materials and methods}

Mature seeds of annatto were collected during October-November 2008 from Kariavattom (Latitude $8^{\circ} 33^{\prime} 03.86^{\prime \prime} \mathrm{N}$; Longitude $76^{\circ} 52^{\prime} 38.64^{\prime \prime} \mathrm{E}$ Altitude $18 \mathrm{~m}$ above sea level) and the dye was eluted using 3 different solvent systems; alkaline water of pH 10 (Extract 1), 90\% ethanol (Extract 2) and chloroform: ethanol mixture 1:3 (Extract 3). The dye was extracted for $24 \mathrm{~h}$ and the solvents were evaporated. The recovered powder was then dissolved in water and diluted to different concentrations $(0.1,0.5$ and $1 \%)$. Besides, a synthetic dye-orange red (contains Sunset yellow FCF CI 15985, Red carmine CI 14720; Mfd. by Bharani Chemicals Co. Chennai, India) that

\footnotetext{
*Corresponding author, e-mail: easiril@yahoo.com
} 
Table 1. Effect of Annatto dye extract and orange red on mitotic behaviour of onion root tips

\begin{tabular}{|c|c|c|c|c|c|c|}
\hline \multirow{2}{*}{ Treatment } & \multirow{2}{*}{$\begin{array}{l}\text { Total no. } \\
\text { of cells } \\
\text { counted }^{\mathrm{a}}\end{array}$} & \multirow{2}{*}{$\begin{array}{l}\text { Mitotic } \\
\text { index }^{\mathrm{a}}\end{array}$} & \multicolumn{4}{|c|}{$\%$ abnormality $^{\mathrm{a}}$} \\
\hline & & & Interphase & Prophase & Metaphase & Anaphase \\
\hline \multicolumn{7}{|l|}{ Annatto dye extract (\%) } \\
\hline \multicolumn{7}{|l|}{ Extract I } \\
\hline 0.1 & $967.7^{\mathrm{e}}$ & $9.18^{\mathrm{e}}$ & $5.80^{\mathrm{c}}$ & $2.80^{\mathrm{fgh}}$ & $4.76^{\mathrm{b}}$ & $5.26^{\mathrm{b}}$ \\
\hline 0.5 & $992.0^{\mathrm{d}}$ & $9.36^{\mathrm{d}}$ & $5.85^{\mathrm{c}}$ & $3.03^{\mathrm{def}}$ & $4.19^{\mathrm{b}}$ & $4.51^{\mathrm{c}}$ \\
\hline 1.0 & $936.7^{\mathrm{f}}$ & $9.36^{\mathrm{d}}$ & $5.49^{\mathrm{c}}$ & $3.12^{\mathrm{de}}$ & $4.34^{\mathrm{b}}$ & $4.76^{\mathrm{b}}$ \\
\hline \multicolumn{7}{|l|}{ Extract II } \\
\hline 0.1 & $1021.3^{\mathrm{e}}$ & $9.58^{\mathrm{bc}}$ & $5.93^{\mathrm{c}}$ & $2.85^{\mathrm{efg}}$ & $4.34^{\mathrm{b}}$ & $3.70^{\mathrm{efs}}$ \\
\hline 0.5 & $989.3^{\mathrm{d}}$ & $9.41^{\mathrm{cd}}$ & $6.01^{\mathrm{c}}$ & $3.06^{\mathrm{de}}$ & $4.73^{\mathrm{b}}$ & $3.84^{\mathrm{de}}$ \\
\hline 1.0 & $1070.7^{\mathrm{a}}$ & $9.70^{\mathrm{ab}}$ & $5.97^{\mathrm{c}}$ & $2.70^{\mathrm{g}}$ & $3.43^{\mathrm{bcd}}$ & $4.46^{\mathrm{c}}$ \\
\hline \multicolumn{7}{|l|}{ Extract III } \\
\hline 0.1 & $966.0^{\mathrm{e}}$ & $9.41^{\mathrm{cd}}$ & $6.10^{\mathrm{c}}$ & $3.19^{\mathrm{bcd}}$ & $4.54^{\mathrm{b}}$ & $3.70^{\mathrm{ef}}$ \\
\hline 0.5 & $925.0^{\mathrm{f}}$ & $9.63^{\mathrm{ab}}$ & $5.85^{\mathrm{c}}$ & $3.41^{\mathrm{b}}$ & $4.00^{\mathrm{b}}$ & $3.84^{\mathrm{de}}$ \\
\hline 1.0 & $1065.7^{\mathrm{a}}$ & $9.44^{\mathrm{c}}$ & $6.05^{\mathrm{c}}$ & $3.36^{\mathrm{bc}}$ & $4.66^{\mathrm{b}}$ & $3.40^{\mathrm{ef}}$ \\
\hline \multicolumn{7}{|c|}{ Orange red (\%): (Negative control) } \\
\hline 0.1 & $1042.0^{\mathrm{b}}$ & $0.00^{\mathrm{g}}$ & $98.3^{\mathrm{a}}$ & $0.00^{\mathrm{i}}$ & $0.00^{\mathrm{cd}}$ & $0.00^{\mathrm{g}}$ \\
\hline 0.05 & $1034.7^{b}$ & $3.65^{f}$ & $84.0^{\mathrm{b}}$ & $42.85^{\mathrm{a}}$ & $53.55^{\mathrm{a}}$ & $63.21^{\mathrm{a}}$ \\
\hline \multicolumn{7}{|l|}{ Positive control } \\
\hline Distilled water & $992.7^{\mathrm{d}}$ & $9.77^{\mathrm{a}}$ & $6.26^{\mathrm{c}}$ & $2.57^{\mathrm{h}}$ & $3.70^{\mathrm{bc}}$ & $4.34^{\mathrm{cd}}$ \\
\hline$F d f(n-1)=11$ & $404.38^{*}$ & $2811.9^{*}$ & $1625.2 \mathrm{I}^{*}$ & $15885.9^{*}$ & $122.3 *$ & $8995.4^{*}$ \\
\hline $\operatorname{LSD}(p<0.5)$ & 6.878 & 0.169 & 2.407 & 0.268 & 3.79 & 0.528 \\
\hline
\end{tabular}

* Significant at $p<0.01$ level.

${ }^{a}$ Means within column followed by same letters are not significantly different as determined by LSD $(p<0.05)$ test.

is added in food to impart similar shades to annatto dye was also used in the study. In a preliminary evaluation, it was evident that orange red concentration exceeding $0.1 \%$ caused a complete inhibition of cell division, thus concentration of this synthetic dye was attuned as 0.1 and $0.05 \%$.

To evaluate the cytotoxicity of annatto extracts, 10 commercial equal-sized A. cepa onion bulbs of 3-4g per concentration were used. They were carefully unscaled and placed on top of test tubes filled with distilled water and allowed to germinate in the dark at $27 \pm 2^{\circ} \mathrm{C}$. After $48 \mathrm{~h}$, healthy onion bulbs in water were used for treatments in various concentrations of annatto extracts. Three extracts (Extract 1, 2 and 3) were diluted to $0.1,0.5$ and 1\% and were used for testing cytotoxicity. Germinated onion bulbs were incubated for $12 \mathrm{~h}$ on top of test tubes filled with different concentrations of annatto dye. To perform the second experiment, 10 equal-sized A. cepa onion bulbs of 3-4g per concentration were used for each treatment. They were carefully unscaled, placed on top of the test tubes, which contained distilled water, and allowed to germinate at $27 \pm 2^{\circ} \mathrm{C}$ for $48 \mathrm{~h}$. After incubation, the germinated onion bulbs were transferred onto the top of the test tube containing different concentrations $(0.05$ and $0.1 \%)$ of orange red solution prepared in distilled water and allowed to germinate at $27 \pm 2^{\circ} \mathrm{C}$ for another $12 \mathrm{~h}$ period. In the third set, $10 \mathrm{~A}$. серa onion bulbs, equal-sized 3-4 g, were allowed to grow and produce new roots on top of the test tube filled with distilled water for $60 \mathrm{~h}$ in the dark at $27 \pm 2^{\circ} \mathrm{C}$. The second set of treatment, where bulbs germinated in the 2 concentrations of orange red, served as a negative control, whereas bulbs germinated in distilled water for $60 \mathrm{~h}$ served as a positive control to compare the effects of dye extract on $A$. cepa root tip. The roots after treatments were fixed in freshly prepared Carnoy's fluid (3 alcohol:1 acetic acid). After an overnight fixation, mitotic preparations were carried out by acetocarmine squash technique (Sharma and Sharma 1990). For photo graphic documentation, an image analyzer system (Olympus, Model No. LH 100HG) was used. The percentage of cells with chromosome abnormalities and mitotic index was calculated by using formula. 

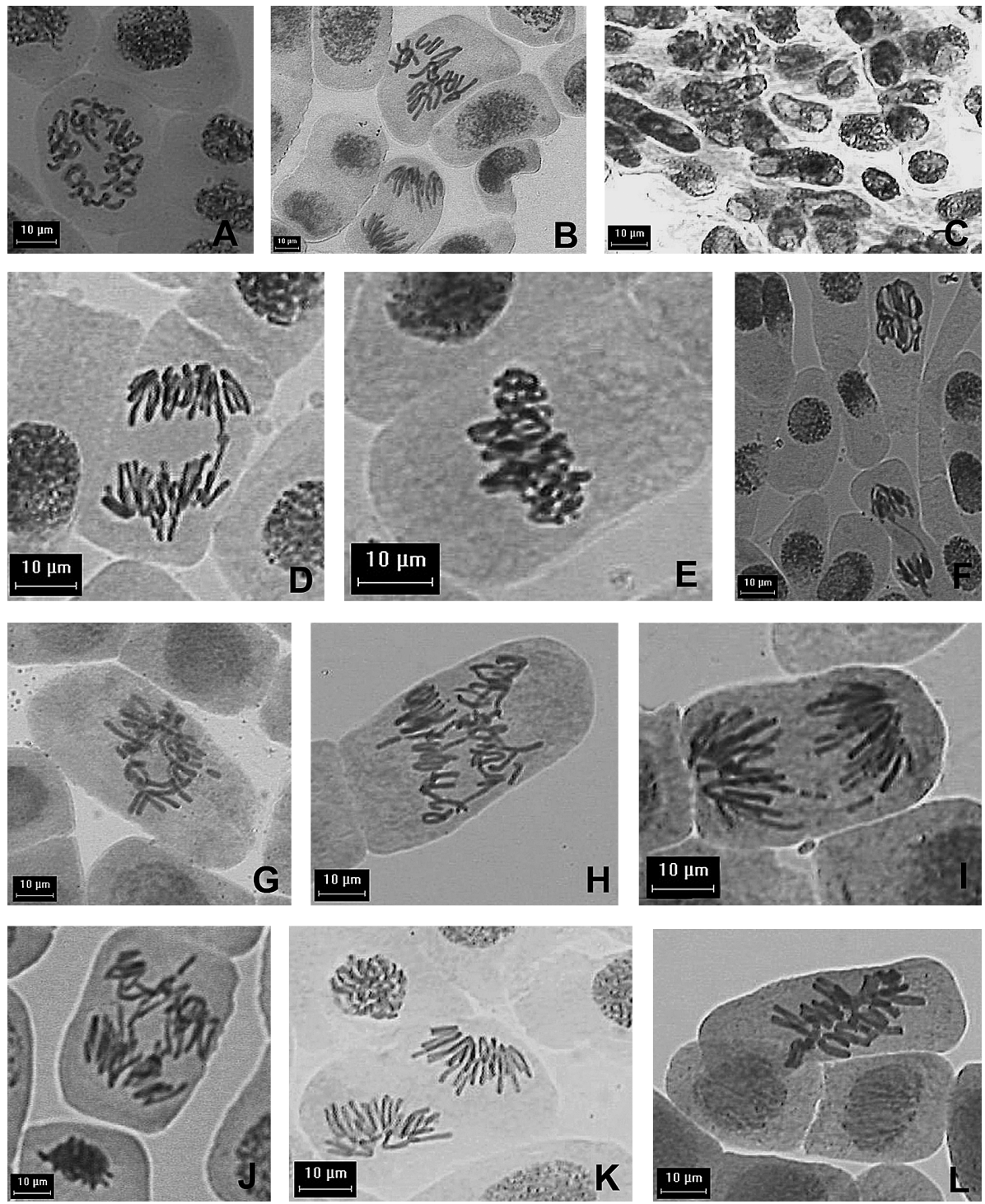

Fig. 1. Mitotic behavior of $A$. cepa root tips treated with annatto (extract $\mathrm{I}, 1 \%, \mathrm{~A}, \mathrm{~B}$ ) and mitotic aberrations in root tip treated with orange red $(\mathrm{C}-\mathrm{L})$. (A) Normal interphase and prophase in annatto dye treated root tip cells. (B) Normal metaphase, anaphase and telophase in annatto treated root tips cells. (C) Complete cell death in orange red $(0.01 \%)$ treated root tip cells-single and double lesions. (D) Chromosome bridge formation in $0.05 \%$ orange red treated root tips. (E) Metaphase clumping. (F) Chromatin bridges and stickiness. (G) Interlocking chromosomes and fragments. (H) Interlocking chromosomes at anaphase. (I) Chromosome fragments at anaphase. (J) Multiple bridges. (K) Tropokinensis. (L) Disorientation in metaphase. Bar $=10 \mu \mathrm{m}$.

$$
\begin{aligned}
& \text { Mitotic index }(\mathrm{MI})=\frac{\text { Total no. of dividing cells }}{\text { Total no. of cells counted }} \times 100 \\
& \text { Percentage of aberrant cells }=\frac{\text { Total no. of aberrant cells }}{\text { Total no. of cells observed }} \times 100
\end{aligned}
$$




\section{Results}

The annatto dye treated root tip cells recorded a comparable level of MI values to the positive control (Table 1). As such, distilled water-treated root tip (positive control) as well as extract II at $1.0 \%$ and extract III at $0.5 \%$ showed significantly $(p<0.05)$ high MI. The values of MI of various annatto treatments ranged from 9.18 to 9.77 . As the concentration of the extract increased, the value of MI was not affected. The normal mitotic behaviour in onion root tip cells treated with annatto extract was observed (Fig. 1A, B). The orange red (0.1\%) treated cells showed complete inhibition of cell division and cell death (Fig. 1C). Treatment in low concentration $(0.05 \%)$ of synthetic dye resulted in significant $(p<0.05)$ reduction in MI $(3.65 \%)$ compared to positive control and annatto extract treated root tips. The orange red $(0.05 \%)$ treated root tips were also characterized by a high percentage of aberrant cells (Table 1). On the other hand, percentage abnormality of the annatto dye treated root tips was recorded as significantly $(p<0.05)$ low (Table 1$)$. Orange red $(0.05 \%)$, treatment registered significantly $(p<0.05)$ high mitotic abnormalities at prophase $(42.85 \%)$, metaphase $(53.55 \%)$ and anaphase $(63.21 \%)$ stages. The highest percentage $(98.3 \%)$ of abnormal interphase nucleus was scored in $0.1 \%$ orange red treated root tips. Nuclear erosion was often observed in root tip cells treated with orange red dye. Both clastogenic and non-clastogenic abnormalities were observed in orange red treated cells which include chromosome bridges (Fig. 1D), metaphase clumping (Fig. 1E), chromosome stickiness (Fig. 1F), interlocking chromosomes and fragments (Fig. 1G,H), chromosome fragments (Fig. 1I), multiple bridges (Fig. 1J), tropokinensis (Fig. 1K) and metaphase disorientation (Fig. 1L). Giant cells and nuclei were frequently observed in synthetic dye orange red treated root tips.

\section{Discussion}

The $A$. сеpa test proved the non-cytotoxic effect of annatto dye. It is in consensus with the biological activity of other natural metabolites that are proved to be least harmful to biological systems. Essentially, natural dyes are biodegradable in nature (Daniel et al. 2006). Certain intrinsic components of the extracts could act as nonspecific redox agents, free radical scavengers, or ligands for binding metals or toxic principles, which could possibly explain the record of the least mitotic abnormalities in annatto extract treated root tips (Sarkar et al. 1996). In the previous report (Aranez and Rubio 1996) on annatto genotoxicity analysis, chloroform extract and petroleum ether extract showed low levels of mitotic index compared to the control. Sub acute treatment of annatto dye for toxicity analysis in rats showed its non-toxic nature (Bautista et al. 2004) is in tune with the present findings. At a lower concentration $(0.05 \%)$ of orange red synthetic dye caused severe mitotic abnormalities.

In the present study it is evident that annatto extract did not induce chromosome aberrations and thus had no cytotoxic effects on $A$. cepa root cells. The cytotoxicity of orange red dye recorded in the present study needs follow-up research including further tests using cell lines and animal systems. The present results warrant the hazard of illegal and indiscriminate use of such synthetic dyes in consumable items. Therefore, profuse use of synthetic colourants like orange red in foodstuffs is to be consciously monitored.

\section{Acknowledgements}

The authors are thankful to Dr. N. Omanakumari, Professor and Head, Department of Botany, University of Kerala, for providing facilities and suggestions. The authors also thank Kerala State Council for Science Technology Environment (KSCSTE) Thiruvananthapuram, Kerala, India for financial support (No. 028, SRSLS/ 2007/ CSTE). 


\section{References}

Aranez, A. T. and Rubio, R. O. 1996. Genotoxicity of pigments from seeds of Bixa orellana L. (Atsuete) I. determined by Allium test. Philip. J. Sci. 125: 259-269.

Bautista, A. R., Moreira, E. L., Batista, M. S., Miranda, M. S. and Gomes, K. 2004. Subacute toxicity assessment of annatto in rat. Food Chem. Toxicol. 42: 625-629.

Daniel, M., Bhattacharya, S. D., Arya, A. and Raole, V. M. 2006. Natural Dyes Scope and Challenges. Scientific Publishers, Jodhpur.

Hagiwara, A., Imai, N., Ichihara, T., Sano, M., Tamano, S., Aoki, H., Yasuhara, K., Koda, T., Nakamura, M. and Shiraj, T. 2003. A thirteen-week oral toxicity study of annatto extract (norbixin), a natural food colour extract from the seed coat of annatto (Bixa orellana L.) in Sprague-Dawley rats. Food Chem. Toxicol. 41: 1157-1164.

Kapoor, V. P. 2006. Dye yielding plants extraction and applications. In: S. K. Bhattacharjee (Ed.). Advances in Ornamental Horticulture. Vol. 5. Pointer Publishers, Jaipur. pp. 219-259.

Leung, Y. A. and Foster, S. 1996. Encyclopedia of Common Natural Ingredients (used in food, drugs and cosmetics). Wiley Interscience Publication, New York.

Paumgartten, F. J., De Carvalho, R. R., Aurujo, I. B., Pinto, F. M., Borges, O. O., Souza, C. A. and Kuriyama, S. N. 2002. Evaluation of developmental toxicity of annatto in the rat. Food Chem. Toxicol. 40: 1595-1601.

Sarkar, D., Sharma, A. and Talukder, G. 1996. Plant extracts as modulators of genotoxic effects. Bot. Rev. 62: 275-300.

Sharma, A. K. and Sharma, A. 1990. Chromosome Technique-Theory and Practices, 3 ed. Butterworth, London. 